\title{
Heavy metal tolerance in indigenous bacteria isolated from the industrial sewage in Kemisan River, Tangerang, Banten, Indonesia
}

\author{
WAHYU IRAWATI ${ }^{1, \boldsymbol{v}}$, SEMUEL RIAK ${ }^{1}$, NIDA SOPIAH ${ }^{2}$, SUSI SULISTIA ${ }^{2}$ \\ ${ }^{1}$ Department of Biology, Teachers College, Universitas Pelita Harapan. Jl. M.H. Thamrin Boulevard 1100, Lippo Karawaci, Tangerang 15811, Banten. \\ Tel. +26215466057, ext. 2615, Fax.+62216450655, ’email: w.irawati3@gmail.com. \\ ${ }^{2}$ Institute of Environmental Technology, Indonesian Agency for Assessment and Application of Technology (BPPT), Building 412 PUSPIPTEK \\ Serpong, Tangerang Selatan 15314, Indonesia
}

Manuscript received: 20 September 2016. Revision accepted: 27 September 2017.

\begin{abstract}
Irawati W, Riak S, Sopiah N, Sulistia S. 2017. Heavy metal tolerance in indigenous bacteria isolated from the industrial sewage in Kemisan River, Tangerang, Banten, Indonesia. Biodiversitas 18: 1481-1486. The bacterial study is a part of human calling in preserving the earth. Many indigenous bacteria isolated from heavy metal contaminated sites had resistance to heavy metal toxicity and could be used for heavy metal removal. The aims of this study were to isolate heavy metal-tolerant indigenous bacteria from the industrial sewage of Kemisan River in Tangerang, Banten, Indonesia. The potency of bacterial isolates to remove heavy metals was also determined. The heavy-metal tolerance was determined by measuring the minimum inhibitory concentration. The potency of bacterial isolate for removing heavy metals from the medium was determined by an atomic absorption spectrophotometer. The results showed that there were eight heavy metal-resistant bacteria isolated from Kemisan River with minimum inhibitory concentration ranging from 7 $\mathrm{mM}$ to $11 \mathrm{mM}$. Isolate PbSI1 was the highest lead tolerant bacteria, and also tolerant to copper and zinc. The isolate was able to remove $91.25 \%$ lead, $73.38 \%$ zinc, and $98.57 \%$ copper from medium supplemented with the mixture of these heavy metals. The addition of 9 $\mathrm{mM}$ of lead in the medium affected the morphological appearance of isolate colonies i.e PbSI1 and PbSI3 to become darker which might occur due to the survival mechanism of bacteria by absorbing the lead inside the cells. The finding of this study indicated that isolate PbSI1 was a promising bacterium, which could be further developed for heavy metal removal.
\end{abstract}

Keywords: Bacteria, biosorption, copper, lead, removal, zinc

\section{INTRODUCTION}

The discharge of heavy metals into aquatic ecosystem has become a matter of concern in Indonesia. Indonesia has several sites contaminated by heavy metals and other residues from the mining industry. For example, most of industrial sewage containing heavy metal pollutants i.e lead, copper, and zinc were illegally introduced into Kemisan River, located in Tangerang, Banten, Indonesia. Andleeb et al. (2010) reported that the chemical water pollution has seriously damaged the ecology of surface and ground water, causing the dangerous effects on living organisms in a polluted area. According to Damini et al. (2013), most of heavy metals and their salts are undegradable or indestructible; moreover, they will remain permanently in the environment. Therefore, the remediation efforts to release heavy metals in the environment is very crucial and very challenging.

Efforts for removing metal ions from aqueous solution has been intensively conducted using technology approaches which mainly consist of physical, chemical and biological technologies. Conventional methods such as chemical precipitation, flocculation, membrane filtration, ion exchange and electrodialysis electrolysis, are often costly or ineffective for removing or reducing the pollutant concentration (Wang and Chen 2009). Bioremediation of heavy metals using microorganisms has received great attention especially for its potential application in industry.
This is because of its nondestructive characters, cheap and economical usages (Rehman et al. 2007). Heavy metaltolerant microorganisms may have a significant role in the soil treatment of metal pollutant. The ability of these microorganisms to detox the metal pollutant can be manipulated for bioremediation purposes especially for removing the heavy metal contamination in both wastewater and soil. Effluents containing heavy metals can be treated with these microorganisms by involving some processes including biosorption, bioaccumulation, and bioprecipitation (Rajbanshi 2008).

Biosorption using bacteria had been studied to sequester metal ions from aqueous solution, which was known as the cheap alternative method compared to conventional processes. This was due to the use of a low-cost sorbent material in biosorption process (Nameni et al. 2008). Bacteria having a potential to accumulate metal can be used to in the metal remediation by removing, concentrating and recovering metals from industrial effluents (Chowdhury et al. 2008). Some reports had shown that indigenous microbes could tolerate high heavy metal concentrations in different ways and may play a significant role in the restoration of a contaminated site (Ge et al. 2009). Isolation of bacteria from metal-polluted environment should be done to find the metal-resistant strain candidates which could be used for heavy metal removal and bioremediation purposes (Malik 2004). Therefore, the aims of this study were to isolate indigenous 
bacteria with high tolerance to heavy metals from the industrial sewage in Kemisan River in Tangerang, Banten, Indonesia and also to study the potency of a bacterial isolate to remove heavy metals.

\section{MATERIALS AND METHODS}

\section{Growth medium}

Bacteria were isolated from industrial wastewater in Kemisan River, Tangerang, Banten, Indonesia. Bacterial isolate was grown in Luria-Bertani (LB) agar containing the following composition (per liter): tryptone $10 \mathrm{~g}$, yeast extract $5 \mathrm{~g}, \mathrm{NaCl} 10 \mathrm{~g}$, and glucose $0.1 \mathrm{~g}$. Stock of $1 \mathrm{M}$ $\mathrm{CuSO}_{4}$ (copper), $1 \mathrm{M} \mathrm{Pb}\left(\mathrm{NO}_{3}\right)_{2}$ (lead), $0.25 \mathrm{M} \mathrm{HgCl}_{2}$ (mercury), and $1 \mathrm{M} \mathrm{ZnSO}_{4}$ (zinc) sterilized by $0.2 \mathrm{~m} \mathrm{PTFE}$ membrane. Appropiate concentration of heavy metal stock solution was added in autoclaved medium. LB agar was made with an addition of $2 \%$ pure agar (Irawati et al. 2015).

\section{Bacterial isolation}

One hundred microliter samples of industrial sewage was serially diluted and inoculated on each medium agar plate supplemented with $3 \mathrm{mM}$ of copper, zinc, and lead. Cells culture was incubated at $37^{\circ} \mathrm{C}$ for 72 hours. The growing colonies on medium were selected followed by purification to obtain a single colony. The morphology of the bacterial cells was observed by Gram staining followed by a light microscope observation.

\section{The effect of heavy metals on bacterial growth}

Initial inoculum was carried out as a starter by inoculating one loop of bacterial pure culture in $50 \mathrm{~mL} \mathrm{LB}$ medium and incubated at $37^{\circ} \mathrm{C}$ on a shaker at $175 \mathrm{rpm}$. The growth of starter was monitored by measuring the optical density (OD) at $\lambda 600 \mathrm{~nm}$ using spectrophotometer. Starter with OD of 0.6 was used for further growth observation. One mililiter of starter was inoculated in $50 \mathrm{~mL} \mathrm{LB}$ broth medium. Each medium was supplemented with $3 \mathrm{mM}$ of copper, lead, cadmium, zinc, the mixture of the heavy metals, and in medium without the heavy metals as a control. The cell cultures were incubated at $37^{\circ} \mathrm{C}$ on a shaker at $175 \mathrm{rpm}$. Bacterial growth was monitored by measuring optical density at $\lambda 600 \mathrm{~nm}$.

\section{Heavy metals tolerance}

The tolerance of bacterial isolates to copper, zinc, and lead were determined by Minimum Inhibitory Concentration (MIC). One loop of bacterial culture was streaked on agar plates containing $3 \mathrm{mM}, 4 \mathrm{mM} 5 \mathrm{mM} 6$ $\mathrm{mM}, 7 \mathrm{mM}, 8 \mathrm{mM}, 9 \mathrm{mM}, 10 \mathrm{mM}, 11 \mathrm{mM}, 12 \mathrm{mM}, 13$ $\mathrm{mM}$ of copper, zinc until the isolate enabled to give colonies. The MICs value was determined after 48 hours of incubation at $37^{\circ} \mathrm{C}$ (Rajbanshi 2008).

\section{Biosorption of heavy metal}

Biosorption is described as the concentration of copper which is removed from growth medium by concerning the initial copper concentration. Bacterial cells were grown in
$50 \mathrm{~mL} \mathrm{LB}$ broth containing $3 \mathrm{mM}$ of copper, zinc, and lead and $1 \mathrm{mM}$ of the mixture of heavy metals. Cell culture was incubated at $37^{\circ} \mathrm{C}$ with shaking at $175 \mathrm{rpm}$. After cell growth underwent logphase lasting, cells culture was centrifuged at $5000 \mathrm{~g}$ for $20 \mathrm{~min}$ at $4^{\circ} \mathrm{C}$ to separate supernatant from the pellet. The supernatant was digested with $\mathrm{HNO}_{3}$ at $100^{\circ} \mathrm{C}$ for measuring the ability of bacteria to biosorp heavy metals. Heavy metals content was determined by using an atomic absorption spectrophotometer at $324.9 \mathrm{~nm}$. Biosorption was calculated as the gap value between the total concentration of heavy metals added to the medium and the remained total concentration of heavy metals in the medium after bacteria were grown. Biosorption efficiency was calculated as (Ci$\mathrm{Cf} / \mathrm{Ci}$ ) $\mathrm{x} 100 \%$ where $\mathrm{Ci}$ is the initial concentration and $\mathrm{Cf}$ is the remaining copper concentration in the solution (Moktar et al. 2011).

\section{RESULTS AND DISCUSSION}

\section{Bacterial isolation}

Kemisan River is one of heavy metals polluted areas in Indonesia caused by the increase of industrial activities around this site. Previous studies showed that many heavymetal resistance in indigenous bacteria could be isolated from heavy metal-contaminated sites (Irawati et al. 2012). This study showed that eight heavy metal-tolerant bacteria were successfully isolated from Kemisan River designated as strains $\mathrm{CuA}, \mathrm{CuB}, \mathrm{PbSI} 1, \mathrm{PbSI}$, PbSI3, PbSI4, ZnSI1 and $\mathrm{ZnSI} 2$. Of all those strains, it showed that the MIC value of Copper-tolerant strains (CuA\& $\mathrm{CuB})$; Leadtolerant strains (PbSI1, PbSI2, PbSI3, and PbSI4), and Zinc-tolerant strains (ZnSI1 and ZnSI2) were as follows: $10 \mathrm{mM} \mathrm{CuSO}_{4}$, from $10 \mathrm{mM}$ to $11 \mathrm{mM} \mathrm{Pb}\left(\mathrm{NO}_{3}\right)_{2}$, and between $7 \mathrm{mM}$ to $10 \mathrm{mM} \mathrm{ZnCl}_{2}$ (Table 1). The variation of the metals tolerance might be due to the presence of different types of tolerance mechanisms which could be seen from the varied isolates (Ezzouhri et al. 2009). Interestingly, the heavy-metal tolerance of bacterial isolates found in this study $(10 \mathrm{mM} \mathrm{CuSO})_{4}$ was higher than Sphingomonas sp. and Stenotrophomonas sp. isolated from copper-polluted agricultural soil in Valparaiso Region, Central Chile. These bacteria were tolerant to copper with MIC value ranging from 3.1 to $4.7 \mathrm{mM}$ (Altimera et al. 2012). In addition, copper-resistant Pseudomonas spp.and cadmium-resistant Acinetobacter spp. isolated from Guherwori sewage treatment plant showed resistance to heavy metals with MICs ranging from 2-4 mM (Rajbanshi 2008).

Six Gram-negative bacteria and two Gram-positive bacteria were successfully isolated from Kemisan River, Tangerang (Table 1). This is in accordance with the findings of previous study in which the majority of the isolates undergoing selection pressures in the presence of toxic compounds were Gram-negative followed by Grampositive isolates accounting for only $20 \%$ (Brynhildsen et al. 1988). Adel et al. (2014) also reported that most of bacteria such as Bacillus sp., Pseudomonas sp., Chryseomonas sp., Burkholderia sp., Citrobacter sp. and 
Table 1. The heavy metals MIC of bacterial strains isolated from Kemisan River, Tangerang, Banten, Indonesia

\begin{tabular}{lclc}
\hline Isolate code & $\begin{array}{c}\text { MIC } \\
(\mathbf{m M})\end{array}$ & Heavy metals & Type of gram \\
\hline $\mathrm{CuA}$ & 10 & $\mathrm{CuSO}_{4}$ & - \\
$\mathrm{CuB}$ & 10 & $\mathrm{CuSO}_{4}$ & + \\
$\mathrm{PbSI} 1$ & 11 & $\mathrm{~Pb}^{\left(\mathrm{NO}_{3}\right)_{2}}$ & - \\
PbSI2 & 11 & $\mathrm{~Pb}\left(\mathrm{NO}_{3}\right)_{2}$ & + \\
PbSI3 & 10 & $\mathrm{~Pb}\left(\mathrm{NO}_{3}\right)_{2}$ & - \\
PbSI4 & 10 & ${\mathrm{~Pb}\left(\mathrm{NO}_{3}\right)_{2}}^{2}$ & - \\
ZnSI1 & 7 & $\mathrm{ZnSO}_{4}$ & - \\
ZnSI2 & 7 & $\mathrm{ZnSO}_{4}$ & - \\
\hline
\end{tabular}

Note: $+=$ Gram-positive, - = Gram-negative

Kluyvera sp. isolated from secondary effluent were $35.7 \%$ Gram-positive and 64.28\% Gram-negative. In addition, Keramati et al. (2011) reported that each of Gram-positive bacteria isolated from dental clinic effluent had no tolerance to heavy metal.

Generally, the contaminated sites are sources of metal tolerant microorganism. The discharge of industrial wastewater containing heavy metals caused the increase population of heavy metal-tolerant bacteria. The higher concentration of these heavy metals remaining above threshold levels has a deleterious impact on the functional activities of microbial communities in soil. However, microorganism may develope tolerance against the elevated levels of these metals as survival mechanism toward the exposition of the higher concentrations of toxic heavy metals (Habi and Daba 2009). The interaction between heavy metals and microbes occurs in nature. Microorganisms can interact with metals via many mechanisms, some of them may be used as the basis of potential bioremediation strategies (Ahemad 2012). The interaction between metals and bacteria depends on the functional groups contained in the cell wall of Grampositive or Gram-negative. The cell wall of Gram-positive bacteria naturally carries a negative charge because their phosphate group and teichoic acid will bind and then regulate the movement of cations across the membrane. Moreover, the outer membrane of Gram-negative bacteria, which consists of lipopolysaccharides, lipoproteins, and phospholipids, carries a strong negative charge (Tortora et al. 2005). Zaied et al. (2008) suggested that numerous chemical groups contributing to biosorption metal will bind hydroxyl, carbonyl, carboxyl, sulfhydryl, and phosphodiester groups. Velkova et al. (2012) assumed that carboxyl groups played a key role in $\mathrm{Cu}$ (II) removal from aqueous solution, followed by hydroxyl groups, phosphate, and amino groups. Carboxyl and hydroxyl groups have a negative charge and probably the electrostatic attraction, which may associate with the major mechanism involved in $\mathrm{Cu}$ (II) biosorption.

The strains of bacterial communities growth in medium containing lead, mercury, copper, and zinc were presented in Figure 1. The higher bacterial community was bacteria growing in medium containing lead, copper, zinc, and mercury, respectively. It indicated that Kemisan River was polluted by these heavy metals. Ahemad (2012) found that the higher concentration of these metals had a great effect on the microbial communities in soil in several ways including (i) the reduction of total microbial biomass, (ii) the decreased number of specific populations, or (iii) the changes of microbial community structure.

Two highest lead tolerant bacteria designated as isolates $\mathrm{PbSI} 1$ and PbSI3 with the MIC value of $11 \mathrm{mM}$ were used for the further research. There was a difference of colonies color when the isolates PbSI1 and PbSI3 were grown in medium supplemented with 7-10 $\mathrm{mM}$ of lead. Based on Table 1, the MIC of isolate PbSI3 was $10 \mathrm{mM}$. It means that there was no colonies growth of isolate PbSI3 in medium with an addition of $11 \mathrm{mM}$ of lead (Figure 2).

The colonies colors of isolates PbSI1 and PbSI3 in medium containing $9 \mathrm{mM}$ of lead treatment were darker than that in the lower concentrations. It might be due to the survival mechanism of bacterial isolates by accumulating the lead inside the cells. The same results were previously observed in Yarrowia lipolytica which could grow at the high concentration of copper sulfate and also developed a brown pigment that could bind metal located in the cell wall (Ito et al. 2007). Bacterial isolates produced darkcolored colonies when grown in the presence of $\mathrm{Ni}^{2+}$. Bacterial isolates that formed a dark color inside the colony might be caused by reduction and precipitation of the metals. It was considered that these isolates were to be $\mathrm{Ni}^{2+}$ biosorbents. No dark color was observed around the colonies of the sensitive bacteria (Abdel-Monem et al. 2010).

It was probably that the increase of lead concentration induced bacteria to develop resistance mechanism through the bioaccumulation of lead inside the cells resulted in the changes of colony appearance to become darker along with the increased concentration of lead. This result was similar to another findings in transgenic bacteria that tolerant to mercury namely Escherichia coli (Ruiz et al. 2011). It has been suggested that the appearance of transgenic bacteria expressing metallothionein and polyphosphate kinase, grown in high mercury concentrations demonstrated cell aggregation, precipitation, and darker color. These effects might also depend on the ability of transgenic bacteria to tolerate and to accumulate the high concentration of mercury due to the presence of metallothionein. This might also explain why the darker color of isolate PbSI1 appeared when it was grown in medium containing $8 \mathrm{mM}$ of lead. This was due to the presence of metallothionein when the isolate was grown in high lead concentration.

The growth of isolate PBSI1 in medium containing zinc, copper, lead, and the mixture of these heavy metals was presented in Figure 3. The growth of isolate PbSI1 in medium containing heavy metals was slower than that in medium without the addition of heavy metals. Isolate PbSI1 grew well in medium containing lead which might happen due to the well-development of lead tolerance mechanism resulted in the lead-tolerant bacteria. The growth of isolate PbSI1 in medium containing copper was slower than that in medium with the addition of other heavy metal. Copper is a metallic element that crucial for cell metabolism; however, in extcessed concentration, it becomes toxic to all living organisms, including bacteria, 


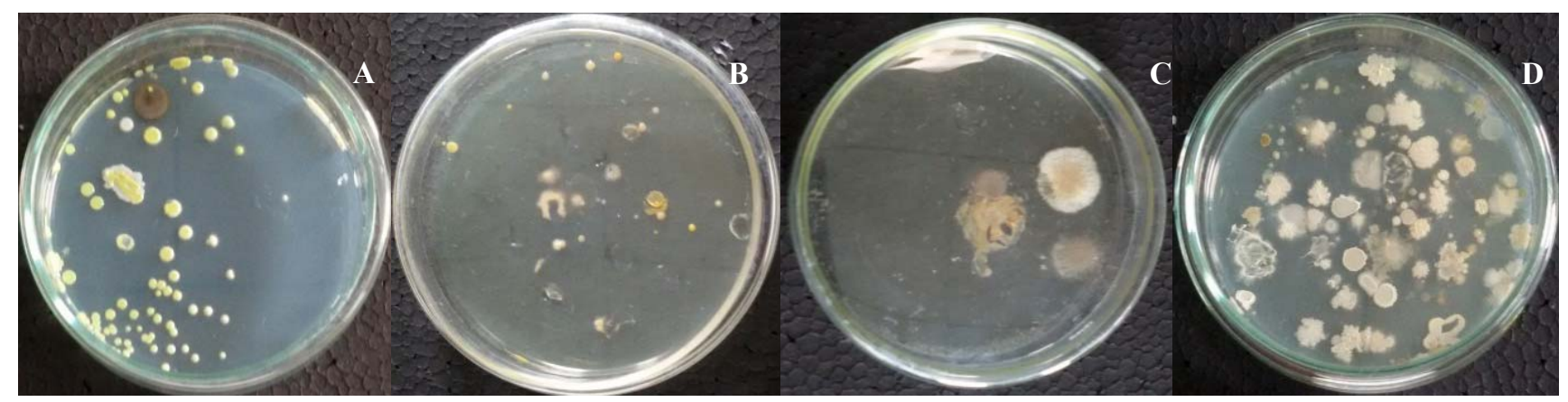

Figure 1. The growth of bacterial colonies communities isolated from Kemisan River, Tangerang, Banten, Indonesia on medium containing various concentrations of heavy metals: (A) $4 \mathrm{mM} \mathrm{ZnSO}_{4}$, (B) $5 \mathrm{mM} \mathrm{CuSO}_{4}$, (C) $0.1 \mathrm{HgCl} 2$, (D) $2 \mathrm{mM} \mathrm{Pb}\left(\mathrm{NO}_{3}\right)_{2}$

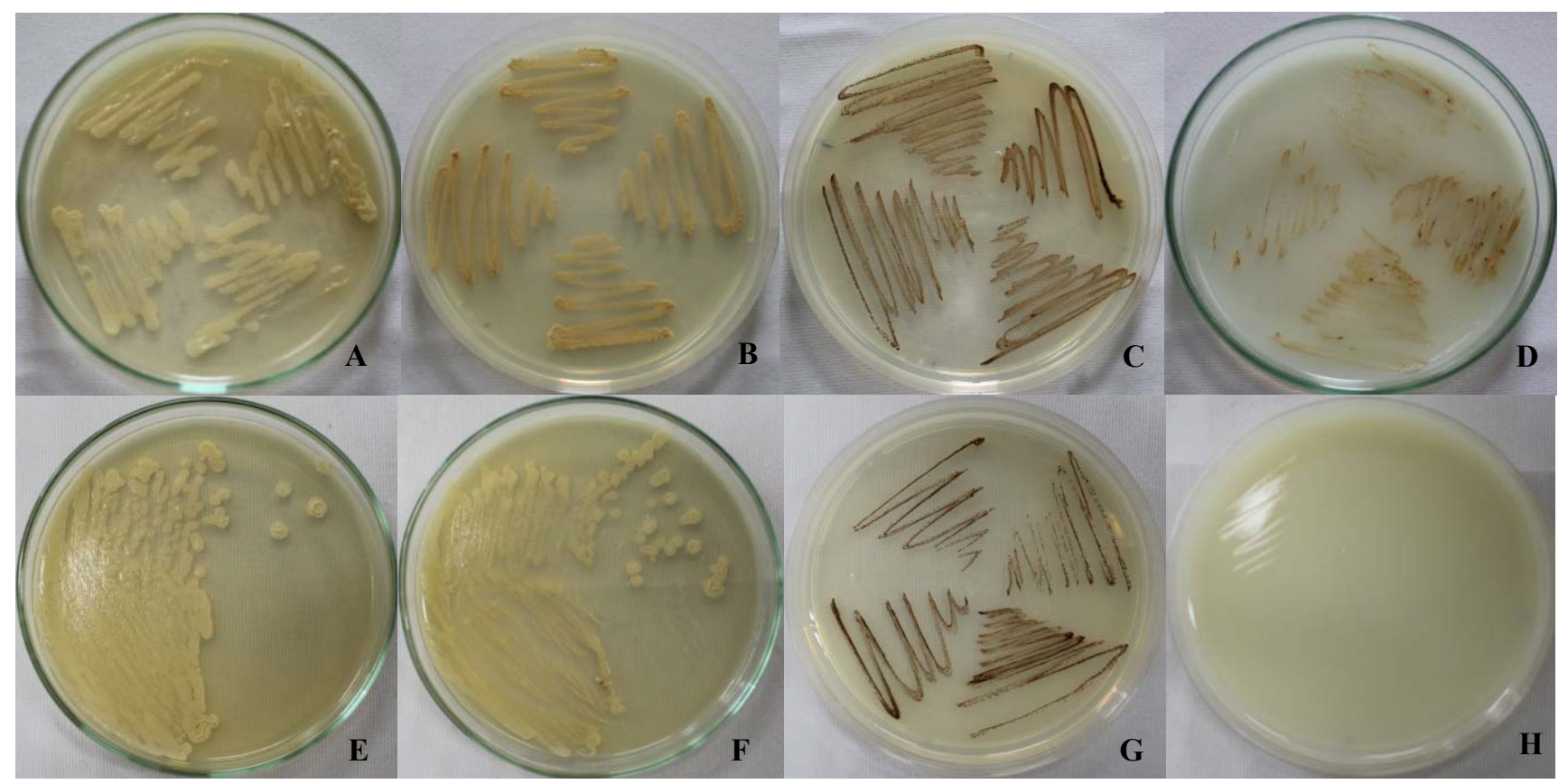

Figure 2. The growth of isolates PbSI1 and PbSI3 on medium containing various concentrations of lead. (A) PbSI1 7 mM, (B) PbSI1 8 mM, (C) PbSI1 9 mM, (D) PbSI1 10 mM, (E) PbSI3 7 mM, (F) PbSI3 8 mM, (G) PbSI3 9 mM, (H) PbSI3 10 mM

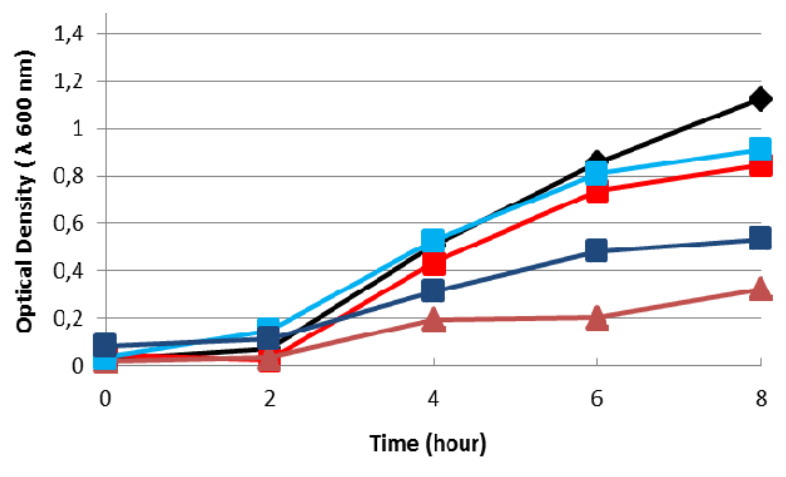

Without heavy metal $\rightarrow-\mathrm{Zn}-\mathrm{Cu}=\mathrm{Pb}-\mathrm{P}-$ Mixture of $\mathrm{Zn}, \mathrm{Cu}, \mathrm{Pb}$

Figure 3. The growth of isolate PBSI1 in medium containing 3 $\mathrm{mM}$ of zinc, copper, lead, and $1 \mathrm{mM}$ the mixture of these heavy metals. which mostly keep a tight hold of copper in the cells (Bondarczuk and Piotrowska-Seget 2013). Copper degrades iron-sulfur clusters of dehydratases through iron displayed, causing the inactivation of these crucial enzymes (Macomber and Imlay 2009).

The MIC test on isolate PbSI1 showed that this isolate was not only tolerant to lead, but also tolerant to zinc, copper, and the mixture of these heavy metals (data were not shown). It indicated that isolate PbSI1 had multiple tolerance to heavy metals. Rajbanshi et al. (2008) assumed that about $52.23 \%$ of bacteria had multiple resistance to three and more heavy metals. A previous study had revealed that $60 \%$ of bacterial isolates from a wastewater treatment plant had multiple tolerance to heavy metals. The bacterium which has multiple tolerance to many heavy metals can be used as a biosorbent efficiently, because polluted metal environment usually was contaminated by more than one type of heavy metals. 


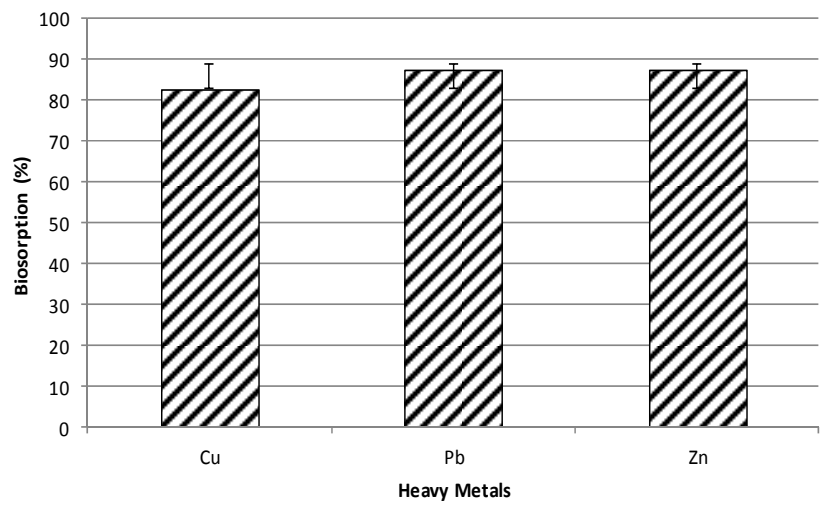

Figure 4. Biosorption percentage of isolate PbSI1 in medium containing $3 \mathrm{mM}$ copper, lead and zinc

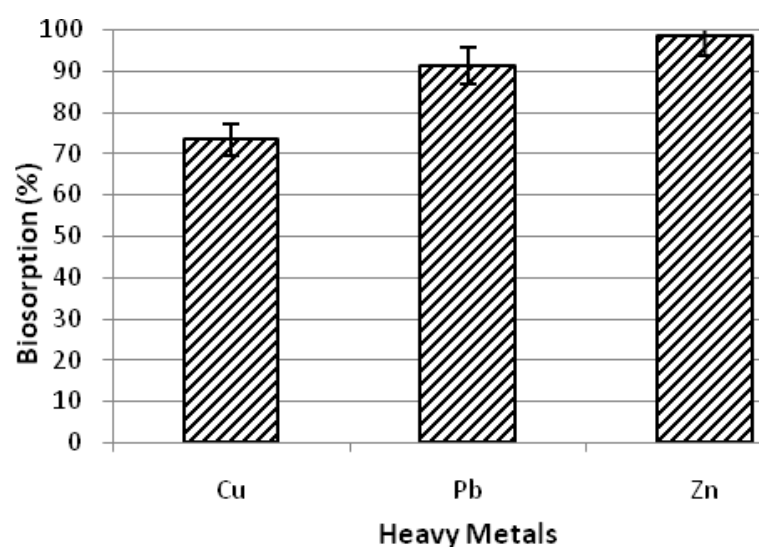

Figure 5. Biosorption percentage of isolate PbSI1 in medium containing the mixture of $1 \mathrm{mM}$ copper, lead and zinc

The most of the bacterial genera has evolved numerous mechanisms to tolerate heavy metal ions and to protect their cell homeostasis against toxicity of heavy metals. Microorganisms can interact with metals via many mechanisms, such as biooaccumulation and biosorption processes (Ahemad 2012). According to Kadukova and Vircikova (2005), bioaccumulation is an intracellular metal accumulation by living cells. Sometimes, it called an active biosorption. Biosorption can bind heavy metallic species to live cells, an inert biomass or to a microbial extracellular polymer (da Silva Oliveira et al. 2007). A wide variety of living and dead biomass of bacteria have a capability to sequester toxic metals from waste streams, which offer an economical alternative for sorption technologies. Once, the toxic metals are adsorbed and/or transferred within organic materials; they can be removed from wastewater (Smith and Collins 2007). Isolate PbSI1 removed lead, copper, and zinc up to $87.68 \%, 82.53 \%$ and $87.69 \%$ in medium containing $3 \mathrm{mM}$ of those heavy metals, respectively (Figure 4). The capablity of Isolate PbSI1 to remove heavy metlas was higher than previous study. Tolerant bacteria isolated from secondary effluents could remove $61.9 \%$ of lead and $74.61 \%$ of copper (Adel et al. 2014). Bacillus sp. isolated from an electroplating industrial effluent sample using copper for plating had an ability to remove up to $69.34 \%$ of copper (Rani et al. 2010). Biosorption capability of Sienotrophomonas maltophilia from primary solution was $22 \%$ of copper and $42.75 \%$ of lead (Parungao et al. 2007).

Isolate PbSI1 was also capable of removing lead, copper and zinc up to $91.25 \%, 73.38 \%$ and $98.57 \%$ from medium supplemented with $1 \mathrm{mM}$ of these mixed heavy metals, respectively (Figure 5). This is a valuable finding since more than one type of heavy metals was contained in most of contaminated sites. It means that isolate PbSI1 is potential isolate which can be used for removing wastewater containing copper, zinc, and lead.

In conclusion, isolate PbSI1 has a great potential to be further developed. Indigenous bacteria may provide new information about the diversity and also has a potential role to remove heavy metals contamination from industrial sites. The potency of bacterial isolates to grow and remove heavy metals would be useful in the application of wastewater treatment plant where bacteria are directly involved as a bioremediation agent in biological processes for wastewater treatment.

\section{ACKNOWLEDGEMENTS}

This research was funded by Hibah Bersaing Project 2016. We would like to thank Yubali Ani from Universitas Pelita Harapan for taking some pictures of bacterial colonies. We also thank students of Biology Department, Teachers College, Universitas Pelita Harapan, especially to Dian Aprillia Manase, Mayrina Indah Prasetyowati, and Ricky Yakobus Kota for being very helpful and eager to learn about this project.

\section{REFERENCES}

Abdel-Monem MO, Al-Zubeiry AH, Al-Gheethi AAS. 2010. Biosorption of nickel by Pseudomonas cepacia $120 \mathrm{~S}$ and Bacillus subtilis 117S. Water Sci Technol 61 (12): 2994-3007.

Adel AS, Gheethi A, Norli I et al. 2014. Biosorption of heavy metals and cephalexin from secondary effluents by tolerant bacteria. Clean Technol Environ Policy 16 (1): 137-148.

Ahemad M. 2012. Implication of bacterial resistance against heavy metals in bioremediation: a review. J Inst Integrat Omics Appl Biotechnol 3 (3): 39-46.

Altimera F, Yanez C, Bravo G et al. 2012. Characterization of copperresistant bacteria and bacterial communities from copper-polluted agricultural soils of central Chile. BMC Microbiol 12: 1-12. DOI: $10.1186 / 1471-2180-12-193$.

Andleeb S, Atiq N, Ali MI et al. 2010. Biological treatment of textile effluent in stirred tank bioreactor. Intl J Agric Biol 12 (2): 256-260.

Bondarczuk K, Piotrowak-Seget Z. 2013. Molecular basis of active copper resistance mechanisms in Gram-negative bacteria. Cell Biol Toxicol 29 (6): 397-405.

Brynhildsen L, Lundgren BV, Allard B et al. 1998. Effects of glucose concentrations on cadmium, copper, mercury and zinc toxicity to a Klebsiella spp. Appl Environ Microbiol 54 (7): 1689-1691.

Chowdhury S, Mishra M, Adarsh VK et al. 2008. Novel metal accumulator and protease secretor microbes from east Calcutta wetland. Am J Biochem Biotechnol 4 (3): 255-264. 
Damini D, Sukristi P, Devi CS et al. 2013. Removal of heavy metals from leather industry effluent using Saccharomyces sp. in a packed bed reactor. Res J Eng Technol 4 (2): 53-56.

Da Silva Oliveira A, Bocio A, Trevilato TMB. 2007. Heavy metals in untreated/treated urban effluent and sludge from a biological wastewater treatment plant. Environ Sci Pollut Res Intl 14 (7): 483489.

Ezzouhri L, Castro E, Moya $\mathrm{M}$ et al. 2008. Uptake of lead by Saccharomyces cerevisiae isolated from Tangier a brewery Wastewater. Eur J Sci Res 19 (4): 668-682.

Ge HW, Lian MF, Wen FZ et al. 2009. Isolation and characterization of the heavy metal resistant bacteria CCNWRS33-2 isolated from root nodule of Lespedeza cuneata in gold mine tailings in China. J Hazard Mater 162 (1): 50-56.

Habi S, Daba H. 2009. Plasmid incidence, antibiotic and metal resistance among enterobacteriaceae isolated from Algerian streams. Pak J Biol Sci 12: 1474-1482.

Irawati W, Yuwono T, Hartiko $\mathrm{H}$ et al. 2012. Molecular and physiological characterization of copper-resistant bacteria isolated from activated sludge in an industrial wastewater treatment plant in RungkutSurabaya, Indonesia. Microbiol Indonesia 3: 107-116.

Irawati W, Kusumawati L, Sopiah RN. 2015. The potency of Acinetobacter $\mathrm{sp}$. IrC2 isolated from industrial wastewater treatment plant in Rungkut-Surabaya as a bioremediation agent for heavy metals. Asian J Microbiol Biotechnol Environ Sci 17 (1): 1-7.

Ito $\mathrm{H}$, Inouhe $\mathrm{M}$, Tohoyama $\mathrm{H}$ et al. 2007. Characteristic of copper tolerance in Yarrowia lipolytica. Biometals 20 (5): 773-780.

Kadukova J, Vircikova E. 2005. Comparison of differences between copper bioaccumulation and biosorption. Environ Intl 31 (2): 227232.

Keramati P, Hoodaji M, Tahmourespour A. 2011. Multi-metal resistance study of bacteria highly resistant to mercury isolated from dental clinic effluent. Afr J Microbiol Res 5 (7): 831-837.

Macomber L, Imlay JA. 2009. The iron-sulfur clusters of dehydratases are primary intracellular targets of copper toxicity. Proc Natl Acad Sci USA 106: 8344-8349.

Malik A. 2004. Metal bioremediation through growing cells. Environ Int 30 (2): $261-278$
Mokhtar H, Morad N, Fizri FFA. 2011. Phytoaccumulation of copper from aqueous solutions using Eichhornia crassipes and Centella asiatica. Intl J Environ Sci Dev 2 (3): 205.

Nameni M, Moghadam MRA, Arami M. 2008. Adsorption of hexavalent chromium from aqueous solutions by wheat bran. Int J Environ Sci Tech 5 (2): 161-168.

Parungao MM, Tacata PS, Tanayan CRG et al. 2007. Biosorption of copper, cadmium and lead by copper-resistant bacteria isolated from Mogpog River, Marinduque. Philippines J Sci 136 (2): 155-165.

Rajbanshi A. 2008. Study on heavy metal resistant bacteria in Guheswori sewage treatment plant. Our Nature 6 (1): 52-57.

Rani MJ, Hemambika B, Hemapriya J et al. 2010. Comparative assessment of heavy metal removal by immobilized and dead bacterial cells: A biosorption approach. Afr J Environ Sci Technol 4 (2): 077-083.

Rehman A, Shakoori FR, Shakoori AR. 2007. Heavy metal resistant Distigma proteus (Euglenophyta) isolated from industrial effluents and its possible role in bioremediation of contaminated wastewaters. World J Microbiol Biotechnol 23 (6): 753-758.

Ruiz ON, Alvarez D, Ruiz GG et al. 2011. Characterization of mercury bioremediation by transgenic bacteria expressing metallothionein and polyphosphate kinase. BMC Biotechnol 11: 82-89. DOI: $10.1186 / 1472-6750-11-82$.

Smith JL, Collins HP. 2007. Management of organisms and their processes in soils. In: Eldor AP (ed). Soil Microbiology, Ecology, and Biochemistry. Elsevier, Burlington.

Tortora GJ, Funke DR, Case CL. 2005. Microbiology: An Introduction. 8th ed. Benjamin Cummings, San Fransisco, CA.

Velkova Z, Stoytcheva M, Gochev V. 2012. Biosorption of $\mathrm{Cu}$ (II) onto chemically modified waste mycelium of Aspergillus awamori: Equilibrium, kinetics and modeling studies. J Biosci Biotechnol 1 (2): 163-169.

Wang J, Chen C. 2009. Biosorbents for heavy metals removal and their future. Biotechnol 27: 195-226.

Zaied KA, Abd El-Mageed HN, Fayzalla EA, Sharief AE. 2008. Enhancement biosorption of heavy metals from factory effluents via recombinants induced in yeast and bacteria. Aust Basic Appl Sci 2 (3): 701-717. 